\title{
PENURUNAN KADAR Pb DALAM KERANG HIJAU (Mytilus virids) DENGAN FILTRAT TOMAT (Solanum Iycopersicum) Tahun 2016
}

\author{
Adistya Galih P, Narwati, Bambang Sunarko
}

\begin{abstract}
Green mussels on the Kenjeran beach contains $1.833 \mathrm{mg} / \mathrm{kg}$ heavy metals Pb. Excessively accumulated heavy metals in the body can lead to death or illness in a short time. This study aims atdetermining the difference levels of Pb decreased in green mussel (Mytilusvirids) with a different concentration of the filtrate tomatoes.

This study is an experimental research using one group pretest posttest design. The dependent variable in this study is the heavy metals Pb concentration in green mussel. The independent variable is the filtrate tomatoes concentration (25\%, 50\%, 75\%, 100\%) with 60 minutes soaking time. To determine the decrease levels effect of heavy metals Pb concentration, researcheruses One Way Anova test becausethe data has normal distribution.

The results shows that the average content of Pbbefore treatment (control) is $0.20 \mathrm{mg} / \mathrm{Kg}$. Afterthe treatment, the highest decrease of $\mathrm{Pb}$ is at $75 \%$ concentration that is $0.12 \mathrm{mg} / \mathrm{kg}$ with a percentage decrease of $60 \%$.

It can be concluded that there is an influence of filtrate tomatoes concentration to decreased levels of heavy metals $\mathrm{Pb}$ in green mussel. It is suggested to people to soak the mussels before consumption by using tomatoes filtrate because it can reduce the level of heavy metals Pb contained in crestacea, especially green mussel.
\end{abstract}

Keywords : green mussels, heavy metals $\mathrm{Pb}$, tomato filtrate

\section{PENDAHULUAN}

Kerang hijau (Mytilus virids) merupakan salah satu produk perikanan non - ikan yang telah lama di dikonsumsi oleh penduduk Indonesia, terutama yang bermukim dipesisir pantai. Produk makanan laut ini banyak digemari para pecinta seafood dan dapat dijumpai di pinggir jalan hingga di restoran dan hotel berbintang (Ghufran, M 2011 : 131). Oleh sebab itu kerang banyak dibudidayakan atau dijual khususnya di daerah Pantai Kenjeran. Pantai Kenjeran yang berada di timur Surabaya merupakan tempat akumulasi dari beberapa badan air di Surabaya dan diberitakan telah tercemar oleh merkuri $(\mathrm{Hg})$ dan $\mathrm{Pb}$ (Ornella, Chony dan Mangkoedihardjo, S, 2011). Menurut Palar, H., (2004 : 80) secara alamiah, $\mathrm{Pb}$ dapat masuk ke badan perairan melalui pengkristalan $\mathrm{Pb}$ di udara dengan bantuan air hujan, sertamelalui proses korosifikasi dari batuan mineral akibat hempasan gelombang dan angin. $\mathrm{Pb}$ masuk ke dalam badan perairan sebagai dampak dari aktivitas kehidupan manusiaberupalimbahcair dari industri baterai, air buangan dari pertambangan bijih timah hitam dan buangan sisa baterai. Logam ini sangat beracun jika terlepas dan terhirup, atau tertelan di dalam tubuh yang dapat mempengaruhi hampir setiap organ dan sistem dalam tubuh termasuk sistem saraf.

Menurut Ridhowati, S.,(2013 : 1) logam berat dianggap berbahaya bagi kesehatan bila terakumulasi secara berlebihan atau melebihi ambang batas $0,2-2,0 \mathrm{mg}$ perhari di dalam tubuh yang berakibat kematian atau gangguan kesehatan dalam waktu yang singkat seperti di dalam ginjal dan hati selama 40hari. Kadar $\mathrm{Pb}$ dalam darah diatas $80 \mathrm{mg} / \mathrm{dl}$ dapat mengakibatkan ensefalopati, keadaan ini disertai ataksia, koma dan kejang - kejang. Pada tingkat $40-50 \mathrm{mg} / \mathrm{dl}$ berakibat IQ menurun. Hal ini diperkuat dengan adanya penelitian (Ali dan Rina, 2010), bahwa pada masyarakat nelayan di Kenjeran mengandung kadar logam berat $\mathrm{Pb}$ pada darah anak - anak di Kenjeran sebesar 59,62 mikrogram/dl. Menurut Banjuri (2003), kadar Pb pada kerang hijau (Mytilus virids) di pantai Kenjeran sebesar $1,883 \mathrm{mg} / \mathrm{kg}$. Menurut hasil kesimpulan Sari, F dan Keman, Soedjaji (2005) mengatakan bahwa biota laut yang hidup di pantai kenjeran telah tercemar logam berat. Alternatif dalam penurunan kadar $\mathrm{Pb}$ pada bahan pangan sehingga aman untuk dikonsumsi dengan menggunakan asam sitrat (Meidianasari F, 2010).

Asam Sitrat merupakan asam organik yang dapat larut dalam air. Asam sitrat mampu membentuk senyawa kompleks dengan logam karena bersifat mengikat logam (chelating agent) sehingga dapat membebaskan bahan makanan dari cemaran logam (Meidianasari F, 2010). Buah tomat (Solanum lycopersicum) merupakan salah satu buah yang mengandung asam sitrat. Dalam penelitian (Masithoh, Rudiati Evi,dkk.,2013) buah tomat dengan varietas kaliurang memiliki asam sitrat sebesar 6,52\%. Hasil uji skrinning terhadap 4 jenis buah tomat diketahui bahwa Tomat gondol ( Lycopersicum validum ) memiliki kandungan asam sitrat $28,23 \mathrm{mg} / 100 \mathrm{gr}$, tomat Cherry ( Lycopersicum cerasiforme ) 54,76mg/100gr, dan tomat sayur ( Lycopersicun commune) memiliki kandungan asam sitrat sebesar $30,55 \mathrm{mg} / 100 \mathrm{gr}$.

Hasil penelitian yang dilakukan Ulfah, dkk (2014) menunjukkan bahwa perendaman ikan keting menggunakan filtrat kulit buah nanas yang mengandung asam sitrat dengan konsentrasi $100 \%$ 
selama 60 menit dapat menurunkan kadar $\mathrm{Pb}$ sebesar $76,55 \%$ sedangkan pada konsentrasi $50 \%$ dapat menurunkan kadar $\mathrm{Pb}$ sebesar 61,01\%selama 60 menit.

\section{METODE PENELITIAN}

Penelitian ini adalah penelitian eksperiment dengan menggunakan metode One Group Pretest Posttest dengan satu faktor perlakuan, yaitu variasi konsentrasi $(25 \%, 50 \%, 75 \%, 100 \%)$ dengan waktu rendam selama 60 menit dan dilakukan 4 kali pengulangan.

Sampel dikumpulkan langsung dari nelayan Pantai Kenjeran Surabaya. Perendaman kerang hijau dengan filtrat tomat dilakukan di Laboratorium Politeknik Kesehatan Surabaya dan dianalisis kandungan $\mathrm{Pb}$ nya di Balai Penelitian dan Konsultasi Industri. Penelitian dilaksanakan pada bulan Juni 2016.

\section{HASIL DAN PEMBAHASAN}

Kadar Pb Kerang Hijau Sebelum Perlakuan Perendaman

Hasil pemeriksaan kandungan $\mathrm{Pb}$ pada kerang hijau
Tahapan penelitian dibagi menjadi 3 tahapan, 1) Pembuatan filtrat tomat cerry. Haluskan tomat cerry menggunakan blender. Filtrat tomat cerry disaring menggunakan saringan dan buat pengenceran dalam konsentrasi $100 \%$, 75\%, 50\% dan $25 \%$ dengan cara konsentrasi $100 \%$ dibuat dari $100 \mathrm{ml}$ filtrat tomat tanpa penambahan aquadest, konsentrasi $75 \%$ dengan mengukur filtrat tomat $75 \mathrm{ml}$ ditambah dengan $25 \mathrm{ml}$ aquadest, konsentrasi $50 \%$ dengan mengukur $50 \mathrm{ml}$ filtrat tomat ditambah dengan aquadest $50 \mathrm{ml}$, dan konsentrasi $25 \%$ dibuat dengan mengukur $25 \mathrm{ml}$ filtrat tomat ditambah dengan $75 \mathrm{ml}$ aquadest. 2) Kerang hijau ditimbang sebanyak 50 gram, lalu direndam dalam filtrat tomat yang memiliki konsentrasi $25 \%$, 50\%, 75\%, dan $100 \%$ selama 60 menit. 3) Kerang hijau yang telah direndam tersebut dianalisis kadar $\mathrm{Pb}$ nya menggunakan AAS (Atomic Absorption Spectrometry).

sebelum dilakukan perendaman di dalam filtrat tomat ditunjukkan pada tabel 1

Tabel 1

Kadar Pb Kerang Hijau Sebelum Dilakukan Perendaman dengan Filtrat Tomat

\begin{tabular}{|c|c|c|c|c|c|c|}
\hline \multirow{2}{*}{$\begin{array}{l}\text { Kode } \\
\text { Sampel }\end{array}$} & \multicolumn{4}{|c|}{$\begin{array}{c}\text { Kadar Logam Berat Pb Pada Kerang Hijau (mg/Kg) Pada } \\
\text { Pengulangan Ke- }\end{array}$} & \multirow[t]{2}{*}{ Rerata } & \multirow{2}{*}{$\begin{array}{c}\text { Standart } \\
\text { SNI }(m g / k g)\end{array}$} \\
\hline & 1 & 2 & 3 & 4 & & \\
\hline $\mathrm{K}$ & 0,21 & 0,18 & 0,22 & 0,17 & 0,20 & 1,5 \\
\hline
\end{tabular}

Hasil pemeriksaan $\mathrm{Pb}$ pada kerang hijau sebelum perendaman (control) dalam filtrat tomat dengan selama 60 menit diketahui memiliki rerata sebesar $0,20 \mathrm{mg} / \mathrm{kg}$. Hal ini menunjukkan bahwa kadar $\mathrm{Pb}$ pada control telah memenuhi Standar SNI 7387 tahun 2009 yaitu sebesar 1,5 mg/kg. Menurut Ridhowati S (2013) logam berat $\mathrm{Pb}$ bila terakumulasi secara terus menerus dapat berbahaya bagi kesehatan di dalam tubuh yang dapat mengakibatkan kematian atau gangguan kesehatan bila mengkonsumsi lebih dari $2 \mathrm{mg}$ per hari. Bila kadar $\mathrm{Pb}$ pada darah diatas $80 \mathrm{mg} / \mathrm{dl}$ dapat terjadi ensefalopati, keadaan ini disertai ataksia, koma dan kejang - kejang (Ridhowati S,
2013). Menurut Palar H (2004), Pb masuk kebadan perairan melalui pengkristalan $\mathrm{Pb}$ di udara dengan bantuan air hujan. Disamping itu, proses korosifikasi dari batuan mineral akibat hempasan ombak dan diakibatkan oleh pembuangan limbah industri. Limbah industri yang masuk kedalam suatu perairan akan terjadi proses pengendapan dalam sedimen. Hal ini menyebabkan konsentrasi bahan pencemar dalam sedimen meningkat (Ali dan Rina, 2010). Kerang Hijau merupakan salah satu organisme yang dapat mengakumulasi logam berat $\mathrm{Pb}$, dikarenakan karakteristik kerang yang mencari makan melalui sedimen.

\section{Kadar Pb Kerang Hijau Sesudah Perlakuan Perendaman}

Hasil pemeriksaan $\mathrm{Pb}$ setelah dilakukan perendaman pada filtrate tomat dapat dilihat pada tabel 2 
Tabel 2

Kadar Pb Kerang Hijau Sesudah Dilakukan Perendaman dalam Filtrat Tomat Selama 60 menit

\begin{tabular}{|c|c|c|c|c|c|c|}
\hline \multirow{2}{*}{$\begin{array}{c}\text { Kode } \\
\text { Sampel }\end{array}$} & \multicolumn{4}{|c|}{$\begin{array}{c}\text { Kadar Logam Berat Pb Pada Kerang Hijau }(\mathrm{mg} / \mathrm{Kg}) \text { Pada } \\
\text { Pengulangan Ke }\end{array}$} & \multirow[t]{2}{*}{ Rerata } & \multirow[t]{2}{*}{$\mathrm{pH}$} \\
\hline & 1 & 2 & 3 & 4 & & \\
\hline A & 0,12 & 0,13 & 0,16 & 0,15 & 0,14 & 5 \\
\hline$B$ & 0,12 & 0,11 & 0,10 & 0,09 & 0,11 & 5 \\
\hline $\mathrm{C}$ & 0,08 & 0,10 & 0,07 & 0,06 & 0,08 & 4 \\
\hline D & 0,10 & 0,09 & 0,11 & 0,08 & 0,09 & 4 \\
\hline
\end{tabular}

Keterangan :

$\mathrm{K}=$ Kelompok sampel tanpa perlakuan perendaman ( kontrol )

A $=$ Kelompok sampel sesudah direndam dengan filtrat tomat konsentrasi $25 \%$

$\mathrm{B}=$ Kelompok sampel sesudah direndam dengan filtrat tomat konsentrasi $50 \%$

C = Kelompok sampel sesudah direndam dengan filtrat tomat konsentrasi $75 \%$

D = Kelompok sampel sesudah direndam dengan filtrat tomat konsentrasi $100 \%$

Hasil pemeriksaan kadar $\mathrm{Pb}$ kerang hijau setelah direndam didalam larutan filtrat selama 60 menit menunjukkan bahwa semakin tinggi konsentrasi filtrate tomat akan semakin tinggi penurunan kadar $\mathrm{Pb}$ hingga pada konsentrasi $75 \%$. Penurunan kadar Pb kerang hijau yang direndam dalam $100 \%$ larutan filtrate tomat menunjukkan kadar yang lebih kecil dibandingkan dengan konsentrasi $75 \%$. Hal ini diduga karena semakin pekatnya konsentrasi filtrat tomat akan semakin sulit berpenetrasi kedalam daging kerang. Hal ini

\section{Persentase Penurunan Kadar Pb Kerang Hijau Antar 4 Konsentrasi}

Perbandingan penurunan kadar logam berat $\mathrm{Pb}$ pada kerang hijau antar 4 konsentrasi dapat dilihat pada tabel 3

Tabel 3

PenurunanKadar Pb Kerang Hijau Antar 4 Konsentrasi Filtrat Tomat

\begin{tabular}{ccccccc}
\hline \multirow{2}{*}{ No. } & \multirow{2}{*}{ KODE } & \multicolumn{2}{c}{$\begin{array}{c}\text { Rata-rata Kadar logam Berat Pb Pada } \\
\text { Kerang Hijau }(\mathrm{mg} / \mathrm{Kg})\end{array}$} & \multicolumn{2}{c}{ Penurunan KadarPb } & $\mathrm{pH}$ \\
\cline { 3 - 6 } & & Sebelum & Sesudah & $(\mathrm{mg} / \mathrm{Kg})$ & $\%$ & 5 \\
\hline 1. & A & 0,20 & 0,14 & 0,06 & 30 & 5 \\
\hline 2. & B & 0,20 & 0,11 & 0,09 & 45 & 4 \\
\hline 3. & C & 0,20 & 0,8 & 0,12 & 60 & 4 \\
\hline
\end{tabular}

Keterangan :

$\mathrm{K}=$ Kelompok sampeltanpaperlakuanperendaman( kontrol )

A = Kelompok sampel sesudah direndam dengan filtrat tomat konsentrasi $25 \%$

B = Kelompok sampel sesudah direndam dengan filtrat tomat konsentrasi $50 \%$

C = Kelompok sampel sesudah direndam dengan filtrat tomat konsentrasi $75 \%$

D = Kelompok sampel sesudah direndam dengan filtrat tomat konsentrasi $100 \%$

Berdasarkan hasil uji beda diketahui bahwa filtrat tomat dengan konsentrasi $25 \%$ memiliki $p$ value $=0,032$. Hal ini menunjukkan tidak ada perbedaan yang signifikan kadar logam berat $\mathrm{Pb}$ sebelum dan sesudah perendaman karena $\mathrm{p}$ value $>a(0,05)$. Hal ini diduga konsentrasi $25 \%$ mengandung pelarut aquadest yang lebih tinggi dibandingkan dengan konsentrasi lainnya. Penambahan aquades mengakibatkan kenaikan $\mathrm{pH}$ pada filtrat tomat. Menurut Setiawan., dkk (2012) terbukti bahwa adanya peningkatan nilai $\mathrm{pH}$ larutan karena adanya penambahan aquadest sehingga didapatkan nilai $\mathrm{pH}$ secara berurutan 4,2-4,6 dan $6,62-6,87$. Menurut Ramadhan B. dan Handajani 
M., (2010) pada pH basa, permukaan sel perlahan bermuatan negatif sehingga kemampuan untuk mengikat ion-ion $\mathrm{Pb}$ menjadi berkurang dan kemampuan menyerap logam semakin kecil.

Pada konsentrasi $100 \%$ diketahui penurunan kadar $\mathrm{Pb}$ lebih kecil dibandingkan dengan konsentrasi 75\%. Hal ini diduga adanya faktor lain yang mempengaruhi kemampuan penyerapan logam, diantaranya adalah proses penetrasi filtrat tomat ke dalam daging kerang. Dalam penelitian Melda., dkk (2013) dijelaskan bahwa semakin tinggi konsentrasi yang digunakan dalam perendaman akan mengakibatkan pengerutan pada daging ayam sehingga asam sitrat sulit berpenetrasi kedalam daging. Dalam penelitian lain yang dilakukan Soeparno dalam Purnamasari Endah (2013) menyatakan bahwa penyusutan pada daging dipengaruhi oleh serabut otot, ukuran dan berat daging. Selain itu menurut Purnamasari Endah., dkk (2013), semakin meningkatnya konsentrasi akan mengakibatkan terjadinya penurunan kadar air pada daging karena tekanan osmosis dari daging. Tekanan osmosis ini mengakibatkan terjadinya penurunan kadar air dan meningkatnya kadar protein.

Berdasarkan hasil uji beda statistic menunjukkan ada perbedaan yang signifikan kadar $\mathrm{Pb}$ sebelum dan sesudah perlakuan perendaman dengan menggunakan filtrat tomat $50 \%, 75 \%$ dan $100 \%$. Penurunan kadar logam berat $\mathrm{Pb}$ disebabkan oleh larutan asam sitrat yang mampu membentuk senyawa kompleks dengan logam. Asam sitrat bersifat mengikat logam sehingga dapat membebaskan bahan makanan dari cemaran logam (Meidianasari, 2010). Asam sitrat adalah asam trikarboksilat dimana tiap molekulnya mengandung gugus karboksil dan satu gugus hidroksil yang terikat pada atom karbon, asam sitrat sangat efektif sebagai pengikat logam ion dan mudah larut dalam air (Setiawan dkk di dalam Athifah, 2014). Proses pengikatan ion logam diawali dari asam sitrat yang memiliki tiga gugus karboksil $\mathrm{COOH}$ sehingga terjadi reaksi kimia $\mathrm{PbO}+\mathrm{C}_{6} \mathrm{H}_{8} \mathrm{O}_{7} \cdot \mathrm{H}_{2} \mathrm{O}(\mathrm{aq})=$ $\mathrm{Pb}_{3}\left(\mathrm{C}_{6} \mathrm{H}_{5} \mathrm{O}\right)_{2}$. Gugus karboksil ini dapat melepas proton di dalam larutan membentuk suatu ion yang disebut ion sitrat. Ion sitrat ini dapat berekasi dengan ion logam membentuk garam sitrat (Nurdiani, 2013).

\section{Pengaruh Konsentrasi Filtrat Tomat Terhadap Penurunan Kadar Logam Berat Pb Pada Kerang Hijau}

Berdasarkan hasil uji anova yaitu $p=0,000$ $<$ a $(0,05)$ menunjukkan ada pengaruh jenis konsentrasi terhadap penurunan kadar logam berat $\mathrm{Pb}$. Peningkatan konsentrasi asam berpengaruh terhadap penurunan kadar logam berat. Semakin tinggi konsentrasi asam yang digunakan maka semakin banyak jumlah hydrogen yang berkompetisi dengan ion logam sehingga kekuatan ikatan logam semakin berkurang dan mudah lepas (Laily,2010). Hal ini terbukti didalam penelitian
Ulfah S, dkk., (2014) bahwa penurunan logam berat $\mathrm{Pb}$ pada ikan keting dengan perendaman filtrate kulit nanas yang mengandung asam sitrat $50 \%$ dan $100 \%$ secara berurutan sebesar $61,01 \%$ dan 76,55\%.

Menurut Ulfah., dkk, (2014) pH memiliki peranan yang sangat penting dalam penyerapan logam berat. Hal ini dikarenakan $\mathrm{pH}$ dapat mempengaruhi kelarutan ion logam dalam larutan, Pada $\mathrm{pH}$ basa, permukaan sel perlahan bermuatan negative sehingga kemampuan untuk mengikat ionion logam berat menjadi berkurang dan kemampuan menyerap logam juga semakin kecil (Ramadhan B dan Handajani M, 2010).

\section{KESIMPULAN DAN SARAN}

\section{Kesimpulan}

1. Kadar $\mathrm{Pb}$ kerang hijau sebelum perendaman (kontrol) memiliki nilai rerata $0,20 \mathrm{mg} / \mathrm{kg}$.

2. Kadar logam berat $\mathrm{Pb}$ kelompok $\mathrm{A}$ perendaman konsentrasi $25 \%$ sebesar 0,14 $\mathrm{mg} / \mathrm{Kg}$, kelompok B konsentrasi $50 \%$ sebesar 0,11 $\mathrm{mg} / \mathrm{Kg}$, kelompok C perendaman konsentrasi $75 \%$ sebesar 0,08 $\mathrm{mg} / \mathrm{Kg}$ dan kelompok $\mathrm{D}$ konsentrasi $100 \%$ sebesar 0,09 mg/Kg.

3. Persentase penurunan kadar $\mathrm{Pb}$ tertinggi pada konsentrasi $75 \%$, yakni $0,12 \mathrm{mg} / \mathrm{kg}$ (60\%).

4. Ada pengaruh signifikan konsentrasi filtrate tomat terhadap penurunan kadar logam berat $\mathrm{Pb}$ pada kerang hijau.

\section{Saran}

1. Bagi Masyarakat

Filtrat tomat dapat digunakan sebagai alternative dalam meminimasi kadar $\mathrm{Pb}$ dalam bahan pangan, terutama kerang.

2. Bagi Peneliti Lain

Diperlukan penelitian lanjutan mengenai :
a. Perbedaan konsentrasi dan waktu perendaman
b. Potensi bahan alami lainnya dalam menurunkan kadar logam berat.
c. Mengembangkan penggunaan filtrate tomat terhadap penurunan logam berat lainnya.

\section{DAFTAR PUSTAKA}

Ali M., Rina. 2010. KemampuanTanaman Mangrove Untuk Menyerap Logam Berat Merkuri $(\mathrm{Hg})$ danTimbal $(\mathrm{Pb} 2+)$. Universitas Pembangunan Nasional Veteran. JawaTimur.

Banjuri. (2003). Perbedaan Kadar Pb Dalam Kupang dengan Jenis Kupang awung (Mytilus viridis) dan Kupang Jawa( Musculistasenhausia)

Ghufran, M (2011). Buku pintar budidaya 32 ikan laut ekonomis

Laily, 2002. Keberadaan Merkuri dan Pengaruh Perendaman Larutan Asam terhadap 
Kandungan Gizi serta Daya Cerna Protein pada Ikan Mas (CyprinuscarpioL.).

Masithoh, RudiatiEvi, dkk.,2013. Model Kinetika Perubahan Kualitas Tomat Selama Penyimpanan. http://jtp.ub.ac.id/index.php/itp/article/downlo $\mathrm{ad} / 388 / 750$

Meidianasari, F (2010). Pembuatan Saus Kupang Merah (Musculitasenhausia) Dengan Perlakuan Konsentrasi Asam Sitrat Dan Lama Perendaman Melda., dkk, 2013. Total bakteri, pH, dan kadar air daging ayam broiler setelah direndam dengan ekstrak daun senduduk (Melasto mamalabactricum L.) selama masa simpan.

Ornella, Chony dan Mangkoedihardjo, S. 2011. Pengaruh Penambahan pH Terhadap Removal Logam BeratTimbal (Pb) oleh Bunga Kana (Canna indica) di Kelurahan Tambak Wedi, Kecamatan Kenjeran, Surabaya

Palar, H., 2004. Pencemaran dan Toksikologi Logam Berat. Rineka Cipta. Jakarta

Purnamasari Endah., dkk, 2013. Sifat fisik dan kimia daging sapi yang dimarinasi jus buah pinang (Areca catechu L.)
Ramadhan B dan Handajani M, 2010. Biosorpsi Logam Berat $\mathrm{Cr}$ dengan Menggunakan Biomassa Saccharomyces cerevisae. Bandung: InstitutTeknologi Bandung

Ridhowati, S., 2013. Mengenal Pencemaran Ragam Logam. GrahaIlmu. Yogyakarta

Sari, F dan Keman, Soedjaji 2005. Efektifitas larutan asam cuka untuk menurunkan kandungan logam berat Cadmium dalam daging kerang bulu. http://journal.unair.ac.id/downloadfullpapers-KESLING-1-2-03.pdf

Standart Nasional Indonesia 7387 tahun 2009 tentang Cemaran logam berat pada makanan

Setiawan, TS., Rachmawati, F., Raharjo,2012. Efektivitas Berbagai Jenis Jeruk (Citrus Sp.) Untuk Menurunkan Logam Berat Kadar $\mathrm{Pb}$ dan Cd pada Udang Putih (Panaeus marguiensis)

Ulfah, dkk, 2014. Upaya Penurunan Logam Berat Timbal pada Mystusnigriceps di Kali Surabaya Menggunakan Filtrat Kulit Nanas. http://ejournal.unesa.ac.id/article/9663/33/arti cle.pdf 